\title{
Cardiopulmonary Arrest Following a Single 25 mg Dose of Quetiapine: A Case Report
}

\author{
Pamela Chia1*\#, Lim Chuan Poh2\#, John Ong3,4, Sharon Ong5,6 \\ 1 Division of Anaesthesiology and Perioperative Sciences, Singapore General Hospital, Singapore \\ 2 Department of Pharmacy, Singapore General Hospital, Singapore \\ 3 Department of Medicine, National University of Singapore, Singapore \\ 4 Department of Engineering, University of Cambridge, Cambridge, United Kingdom \\ 5 Department of Surgical Intensive Care, Singapore General Hospital, Singapore \\ 6 Department of Surgical Intensive Care, Sengkang General Hospital, Singapore
}

\begin{abstract}
Introduction: Quetiapine is commonly used in intensive care units (ICU) to treat delirium. Cardiopulmonary arrest caused by low dose quetiapine is unreported. Only two cases in the literature have reported acute respiratory failure after single doses of $50 \mathrm{mg}$ and $100 \mathrm{mg}$ respectively. We report a case of cardiopulmonary arrest in a patient after the administration of a single $25 \mathrm{mg}$ dose of quetiapine. Case presentation: A 72 -year-old Chinese female with multiple cardiovascular co-morbidities was admitted to the ICU intubated, following complications from an elective endovascular repair of an infrarenal abdominal aortic aneurysm. She was alert and extubated the following day. She subsequently showed signs of delirium and was administered a single $25 \mathrm{mg}$ dose of oral quetiapine. Seven hours after ingestion, she developed type 2 respiratory failure and eventually cardiopulmonary arrest. She was successfully resuscitated and other causes for cardiopulmonary arrest were excluded. Twenty-four hours following her cardiopulmonary arrest, her respiratory failure had completely reversed and she was extubated uneventfully. Conclusion: This case report demonstrates that a single dose of oral quetiapine $25 \mathrm{mg}$ is sufficient to cause respiratory failure and cardiopulmonary arrest. Caution is advised when prescribing quetiapine in the elderly, especially in those with impaired drug clearance.
\end{abstract}

Keywords: cardiopulmonary arrest; quetiapine; delirium; respiratory failure, antipsychotics

Received: 30 June 2020 / Accepted: 6 October 2020

\section{INTRODUCTION}

Delirium affects up to $80 \%$ of patients admitted to intensive care units (ICU) and contributes to increased morbidity and mortality [1-3]. It is associated with increased ventilator dependence, length of hospital stay, cost of care, long-term cognitive impairment, post discharge institutionalisation and mortality [3]. Pharmacological management include the traditional use of haloperidol, and alternative drugs like dexmedetomidine and quetiapine [1].

Quetiapine is an atypical antipsychotic drug, which has been shown to be effective in the treatment of mental health conditions. It is also widely used in ICUs because of its efficacy in treating ICU delirium $[2,4,5]$.

Non-overdose quetiapine induced cardiopulmonary arrest in patients is exceedingly rare. Only two cases in the literature have been reported describing acute respiratory failure after single doses of 50mg and $100 \mathrm{mg}[6,7]$.

The case is described of an elderly female who developed cardiopulmonary arrest after receiving a single $25 \mathrm{mg}$ dose of quetiapine.

\section{Case Presentation}

A 72-year-old ethnic Chinese female undergoing haemodialysis, with a history of hypertension, hyperlipidaemia, end stage renal failure (ESRF), transient ischaemic attack, multinodular goitre and gastritis, was diagnosed with a $5.2 \mathrm{~cm}$ infra-renal abdominal aortic aneurysm. She had no history of obstructive sleep apnoea or respiratory failure. Preoperative physical and airway examination were unremarkable. A transtho- 
racic echocardiogram performed in 2014 showed a left ventricular (LV) ejection fraction of $65 \%$, mild left ventricular hypertrophy and mildly impaired LV diastolic function.

She was admitted to the Singapore General Hospital, a tertiary hospital in Singapore for an elective endovascular aneurysm repair of the infra-renal abdominal aortic aneurysm under general anaesthesia on the day of hospital admission.

Intraoperatively, she required ephedrine (Hameln Pharmaceuticals GmbH, Hameln, Germany) and phenylephrine (Unimedic AB, Matfors, Sweden) which were weaned off at the end of the procedure. Postoperatively she was extubated and transferred to the high dependency unit.

On Day 2 post-admission (post-operative Day 1), she complained of backache during haemodialysis. Subsequently, she became hypotensive (BP $72 / 34 \mathrm{mmHg}$ ), bradycardic (heart rate 40 beats/min) and unresponsive, with a Glasgow Coma Scale (GCS) of 3. Dopamine (Hanlim Pharm. Co., Ltd., Gyeong$\mathrm{Gi}$, Korea) was started at $10 \mathrm{mcg} / \mathrm{kg} / \mathrm{min}$, which improved her blood pressure and GCS to 11 (E3V2M6). An urgent computed tomography (CT) aortogram was performed to exclude postoperative bleeding from an aortic rupture or the femoral puncture site. The scan reported no evidence of active haemorrhage or blood flow into the aneurysm sac. Immediately after having the CT scan she was transferred to the hospital's ICU for further management of shock. She was not intubated as she was alert, with a GCS of 15 (E4V5M6). She remained hypotensive but responsive to fluid boluses and blood transfusion. Additionally, her blood pressure was supported with $0.01-0.05 \mathrm{mcg} / \mathrm{kg} / \mathrm{min}$ of noradrenaline (Intega Pte Ltd, Singapore). On Day 2 post-admission to the ICU, a CT scan of the abdomen and pelvis was repeated as there was on-going anaemia, her haemoglobin decreasing from $10 \mathrm{~g} / \mathrm{dL}$ to $7.4 \mathrm{~g} / \mathrm{dL}$. The scan showed active bleeding from the left common iliac artery and a retroperitoneal haematoma. An emergency $\mathrm{x}$-ray guided stent was inserted via the left common iliac artery on the same day. The patient was intubated electively for the procedure and remained haemodynamically stable throughout.

Upon return to the ICU after the procedure, the patient had blood investigations repeated, a transthoracic echocardiogram and initiation of continuous renal replacement therapy (CRRT). The blood investigations showed markedly elevated liver enzymes and troponin
T indicating ischaemic hepatitis and Type 2 myocardial infarction (MI). The transthoracic echocardiogram results indicated a left ventricular ejection fraction as $55 \%$ with no regional wall motion abnormality, nor any other abnormalities.

On Day 3, post-admission to the ICU, inotropes, intravenous sedation and analgesia were ceased. She was alert with a recorded GCS score of 11 (E4VTM6) and was extubated immediately after cessation of a fentanyl infusion (Hospira Australia Pty Ltd, Mulgrave, Australia) of $30 \mathrm{mcg} / \mathrm{hr}$.

Her arterial blood gas (ABG) post extubation on $3 \mathrm{~L} / \mathrm{min}$ oxygen via nasal prongs was $\mathrm{pH} 7.3 \mathrm{pCO}_{2}$ $48.6 \mathrm{mmHg} \mathrm{pO}_{2} \quad 157 \mathrm{mmHg} \mathrm{BE}-0.3 \mathrm{mmol} / \mathrm{L} \quad \mathrm{HCO}_{3}$ $23.9 \mathrm{mmol} / \mathrm{L} \mathrm{SaO}_{2} 99 \%$. No other sedative medications such as opioids, benzodiazepines, anticholinergics nor antihistamines were administered after extubation.

CRRT was suspended after the circuit filter clotted as there was no indication for continuous dialysis. Eleven hours after extubation, the patient became restless and confused with a GCS of 14 (E4V4M6). She also had a positive score for delirium on the Confusion Assessment Method for ICU and the Richmond AgitationSedation Scale.

She did not have a history of dementia, psychiatric illness, epilepsy, or alcohol abuse. On examination, there was no focal neurological deficit and her vital parameters were stable. There were also no infectious foci nor metabolic derangements. Her electrolytes and glucose were within the normal range; glucose $5.5 \mathrm{mmol} / \mathrm{L}$, urea $6.1 \mathrm{mmol} / \mathrm{L}$, sodium $138 \mathrm{mmol} / \mathrm{L}$, potassium $3.8 \mathrm{mmol} / \mathrm{L}$, chloride $103 \mathrm{mmol} / \mathrm{L}$, bicarbonate $24.5 \mathrm{mmol} / \mathrm{L}$, creatinine $161 \mathrm{umol} / \mathrm{L}$, magnesium $1.15 \mathrm{mmol} / \mathrm{L}$, phosphate $0.95 \mathrm{mmol} / \mathrm{L}$, calcium $2.25 \mathrm{mmol} / \mathrm{L}$. Anaemia of $8.5 \mathrm{~g} / \mathrm{dL}$ was noted, and she was transfused with a pint of packed red blood cells, although no active source of bleeding had been located.

Twenty-five $\mathrm{mg}$ of oral quetiapine (Sandoz Illaç Sanayi ve Ticaret A.Ş., Gebze-Kocaeli, Turkey) was administered, twelve hours after extubation to manage her delirium.

Two hours after quetiapine was administered, the patient was noted to be drowsy and her GCS decreased from 14 to 11 (E3V2M6). A repeat $A B G$ on oxygen of $2 \mathrm{~L} / \mathrm{min}$ showed $\mathrm{pH} 7.34, \mathrm{pCO}_{2} 49 \mathrm{mmHg}, \mathrm{pO}_{2}$ $82 \mathrm{mmHg}, \mathrm{BE} 0.6 \mathrm{mmol} / \mathrm{L}, \mathrm{HCO}_{3} 24.6 \mathrm{mmol} / \mathrm{L}, \mathrm{SaO}_{2}$ 95\%. Overnight, apart from tachycardia of 100-108 
beats/min, she was otherwise haemodynamically stable. Her oxygen saturation was $92-95 \%$ on oxygen of $2 \mathrm{~L} / \mathrm{min}$ and respiratory rate was 17 to 20 breaths/min.

On Day 4 post-admission to ICU at $0610 \mathrm{~h}$, seven hours after quetiapine administration, her blood pressure decreased to $74 / 50 \mathrm{mmHg}$ and heart rate to 55 beats/min.

The attending ICU doctor, noted that she was unresponsive with a GCS of 3, and bradypneic with a respiratory rate of less than 12 breaths/min. Her heart rate subsequently slowed to a sinus bradycardia of 40 beats/ min and then progressed to pulseless electrical activity within five minutes of the review. Cardiopulmonary resuscitation (CPR) was commenced at $0620 \mathrm{~h}$ and two intra-venous 1mg boluses of adrenaline (Atlantic Laboratories Corporation Ltd., Samut Prakan, Thailand) were given. She was re-intubated and return of spontaneous circulation was achieved after six minutes of CPR.

An ABG sampled at $0630 \mathrm{~h}$ immediately after resuscitation, showed primary respiratory acidosis, indicating a Type 2 respiratory failure $\left(\mathrm{pH} 6.893, \mathrm{pCO}_{2}\right.$ $168 \mathrm{mmHg}, \mathrm{pO}_{2} 134 \mathrm{mmHg}, \mathrm{BE}-3.9 \mathrm{mmol} / \mathrm{L}, \mathrm{HCO}_{3}$ $19.3 \mathrm{mmol} / \mathrm{L})$. The patient was haemodynamically stable post resuscitation and did not require further inotropic support.

The post resuscitation electrocardiogram at $0640 \mathrm{~h}$ revealed sinus tachycardia with a heart rate of 115 beats/min. The corrected QT interval was not prolonged and there was no elevation of the ST segment.

There was also no expiratory rhonchi on lung auscultation nor witnessed seizures. ABG, renal and liver blood panel were repeated at $0800 \mathrm{~h}$. The results showed an improvement of the hypercarbia and acidosis on assist control ventilation $\left(\mathrm{pH} 7.5 \mathrm{pCO}_{2} 32 \mathrm{mmHg} \mathrm{pO}_{2}\right.$ $98 \mathrm{mmHg} \mathrm{BE} 2.5 \mathrm{mmol} / \mathrm{L} \mathrm{SaO}_{2} 97 \% \mathrm{HCO}_{3} 26 \mathrm{mmol} / \mathrm{L}$ ).

A renal panel investigation revealed no abnormalities (urea $8.3 \mathrm{mmol} / \mathrm{L}$, potassium $4.5 \mathrm{mmol} / \mathrm{L}$, sodium $143 \mathrm{mmol} / \mathrm{L}$, magnesium $1.13 \mathrm{mmol} / \mathrm{L}$, phosphate $2.19 \mathrm{mmol} / \mathrm{L}$, calcium $2.17 \mathrm{mmol} / \mathrm{L}$ and glucose $8.6 \mathrm{mmol} / \mathrm{L}$ ) and the result of her liver panel showed a downward trend of her liver enzymes as compared to that on ICU admission (aspartate transaminase $589 \mathrm{U} / \mathrm{L}$ reduced from $1266 \mathrm{U} / \mathrm{L}$, alanine transaminase $313 \mathrm{U} / \mathrm{L}$ reduced from $614 \mathrm{U} / \mathrm{L}$ ). In addition, post cardiopulmonary arrest, troponin $\mathrm{T}$ levels repeated at $0700 \mathrm{~h}, 1200 \mathrm{~h}$, and $1800 \mathrm{~h}$, also showed a downward trend (troponin T $135 \mathrm{ng} / \mathrm{L}, 167 \mathrm{ng} / \mathrm{L}$, and 86ng/L). A
CT scan of the brain performed soon after resuscitation was reported as normal.

CRRT was recommenced four hours after cardiopulmonary arrest, for fluid removal, as she had a net positive balance of $1.5 \mathrm{~L}$ in the previous twenty-four hours.

She was extubated uneventfully twenty-four hours after her cardiopulmonary arrest. The next day, Day 5 post-admission to ICU, her GCS was recorded as 15 and she was transferred to the high dependency unit of the hospital.

\section{DISCUSSION}

Despite the abundance of literature on ICU delirium, the evidence for pharmacological treatment is weak and controversial $[3,8]$. Commonly used medication include typical antipsychotics such as haloperidol, atypical antipsychotics such as olanzapine and quetiapine, or sedatives such as dexmedetomidine [8]. A comparison of drugs used to treat ICU delirium is given in Table 1. However, current evidence does not support a single effective pharmacologic approach for the treatment of ICU delirium $[3,8,14]$.

Several studies have evaluated the use of quetiapine in ICU, showing its benefit in controlling prolonged delirium with a faster resolution $[2,4,5]$. In a small randomised control trial of ICU patients with delirium, in addition to "as-needed" haloperidol, patients who were administered quetiapine had a faster resolution of the first episode of delirium, were less agitated and had a greater rate of transfer to home or rehabilitation as compared to a placebo [4]. Another retrospective cohort study evaluating quetiapine therapy for hypoactive delirium in ICU demonstrated a significant decrease in the duration of delirium by twelve hours, compared to patients who received standard care without quetiapine [5]. Nonetheless, data from high quality systematic reviews and meta-analysis are lacking. We are not aware of any reports of cardiopulmonary arrest that is caused by a single dose of $25 \mathrm{mg}$ quetiapine in patients without any chronic respiratory condition. A literature search has only shown two case reports of respiratory failure requiring intubation, in patients who did not overdose on quetiapine $[6,7]$. One had a history of chronic obstructive pulmonary disease (COPD) and was treated for pneumonia, whilst the other was subsequently diagnosed with severe obstructive sleep apnoea syndrome 
Table 1. Drugs used for ICU Delirium

\section{Haloperidol}

Mechanism of action

Nonselective blockade of postsynaptic dopaminergic $D_{2}$ receptors in the brain [9]

\section{Quetiapine Dexmedetomidine}

Antagonism of serotonin Selective $\alpha 2-$

5- $\mathrm{HT}_{2}$ and dopamine $\mathrm{D}_{2}$ adrenergic receptor receptors [9] agonist [9]

\section{Olanzapine}

Potent antagonist of serotonin $5-\mathrm{HT}_{2 \mathrm{~A}}$ and $5-\mathrm{HT}_{2 \mathrm{C}}$ histamine $\mathrm{H}_{1}$, dopamine $\mathrm{D}_{1-4}$, and alpha ${ }_{1}$-adrenergic receptors. Moderate antagonist of muscarinic $\mathrm{M}_{1-5}$, and $5-\mathrm{HT}_{3}$ receptors [9]

\begin{tabular}{|c|c|c|c|c|}
\hline Half life & $\begin{array}{l}\text { Decanoate: } \\
21 \text { days } \\
\text { Lactate: } \\
20 \text { hours (Intramuscular } \\
\text { (IM)) } \\
14-26 \text { hours (IV) } \\
14-37 \text { hours (oral) [9] }\end{array}$ & 6 hours [10] & $\begin{array}{l}\text { Up to } 3 \text { hours, signifi- } \\
\text { cantly prolonged with } \\
\text { severe hepatic impair- } \\
\text { ment [9] }\end{array}$ & $\begin{array}{l}\text { Oral and IM: } \\
30 \text { hours; approximately } \\
1.5 \text { times greater in el- } \\
\text { derly [9] }\end{array}$ \\
\hline Metabolism & $\begin{array}{l}\text { Mainly hepatic metabolism } \\
\text { to inactive metabolites [9] }\end{array}$ & $\begin{array}{l}\text { Metabolised by liver to } \\
\text { active metabolites with } \\
\text { low activity levels [10] }\end{array}$ & $\begin{array}{l}\text { Hepatic metabolism } \\
\text { [9] }\end{array}$ & $\begin{array}{l}\text { Mainly hepatic metabo- } \\
\text { lism with } 40 \% \text { removed } \\
\text { via first pass metabolism } \\
\text { [9] }\end{array}$ \\
\hline $\begin{array}{l}\text { Effect with } \\
\text { hepatic } \\
\text { impairment }\end{array}$ & $\begin{array}{l}\text { No dosage adjustment } \\
\text { needed but concentration } \\
\text { may increase in patients } \\
\text { with hepatic impairment } \\
\text { [9] }\end{array}$ & $\begin{array}{l}\text { Higher plasma levels } \\
\text { are expected in the } \\
\text { hepatically impaired } \\
\text { population, and dosage } \\
\text { adjustment may be } \\
\text { needed [11] }\end{array}$ & $\begin{array}{l}\text { No dosage adjustment } \\
\text { recommended but } \\
\text { consider dose reduc- } \\
\text { tion in patients with } \\
\text { hepatic impairment } \\
\text { [9] }\end{array}$ & $\begin{array}{l}\text { No dosage adjustment } \\
\text { needed. Use with caution } \\
\text { in patients with hepatic } \\
\text { impairment [9] }\end{array}$ \\
\hline $\begin{array}{l}\text { Effect with } \\
\text { renal } \\
\text { impairment }\end{array}$ & $\begin{array}{l}\text { No dosage adjustment } \\
\text { needed [9] }\end{array}$ & $\begin{array}{l}\text { Renal insufficiency does } \\
\text { not need dosage adjust- } \\
\text { ments. However, in se- } \\
\text { vere renal impairment, } \\
\text { alterations in protein } \\
\text { binding of quetiapine } \\
\text { may affect its pharma- } \\
\text { cokinetics }[10,11]\end{array}$ & $\begin{array}{l}\text { No dosage adjustment } \\
\text { needed [9] }\end{array}$ & $\begin{array}{l}\text { No dosage adjustment } \\
\text { needed [9] }\end{array}$ \\
\hline $\begin{array}{l}\text { Peak } \\
\text { concentration }\end{array}$ & $\begin{array}{l}\text { Decanoate: } \\
6 \text { days } \\
\text { Lactate: } \\
20 \text { minutes (IM) } \\
\text { 2-6 hours (oral) [9] }\end{array}$ & $1-2 \mathrm{~h} \mathrm{[10]}$ & $\begin{array}{l}\text { IV loading dose: } \\
\text { 15-30 minutes [9] }\end{array}$ & $\begin{array}{l}\text { Short acting injection: } \\
\text { 15-45 minutes } \\
\text { Extended release injec- } \\
\text { tion: } \sim 7 \text { days } \\
\text { Oral: 6 hours [9] }\end{array}$ \\
\hline Advantages & Low treatment cost [9] & $\begin{array}{l}\text { Low risk of EPS (extra- } \\
\text { pyramidal symptoms) } \\
\text { and QTc prolongation } \\
\text { compared to typical } \\
\text { antipsychotics }[1,7]\end{array}$ & $\begin{array}{l}\text { Analgesia and seda- } \\
\text { tion with minimal } \\
\text { respiratory depression } \\
{[12]}\end{array}$ & No QTc prolongation [13] \\
\hline Side effects & $\begin{array}{l}\text { QTc prolongation, drowsi- } \\
\text { ness, hypotension and EPS } \\
\text { [9] }\end{array}$ & $\begin{array}{l}\text { Somnolence, orthostatic } \\
\text { hypotension, and tachy- } \\
\text { cardia [9] }\end{array}$ & $\begin{array}{l}\text { Bradycardia, } \\
\text { hypotension [9] }\end{array}$ & $\begin{array}{l}\text { Orthostatic hypotension, } \\
\text { EPS, weight gain, drowsi- } \\
\text { ness, transaminitis [9] }\end{array}$ \\
\hline
\end{tabular}

[6,7]. Respiratory depression, requiring intubation and mechanical ventilation, is a known complication of quetiapine overdose, although the reported doses were much higher than those received by our patient [15].
There are several plausible pathways underlying antipsychotic-induced acute respiratory failure that is related to the inhibition of serotonin $5 \mathrm{HT}_{2 \mathrm{~A}}$, dopamine $\mathrm{D}_{1}$ and $\mathrm{D}_{2}$, and histamine $\mathrm{H}_{1}$-receptors. These cause in- 
hibition of the respiratory centre in the brainstem with dystonia and collapse of the upper airway muscles [16].

After excluding all other potential causes, quetiapine is the only reasonable cause of the current patient's respiratory failure and subsequent cardiopulmonary arrest as she experienced an acute drop of GCS and loss of pulse, seven hours after quetiapine ingestion. Other causes of respiratory failure are unlikely as she did not have a history of neuromuscular disorder or respiratory disease such as obstructive sleep apnoea, COPD or asthma.

There was also no evidence of a new pneumonia as markers of infection (e.g white cell count, C-reactive protein and procalcitonin) were not elevated and a chest radiograph did not show any consolidation. Metabolic factors causing a depressed conscious state were also excluded from her biochemistry results and no other sedatives were administered after extubation. In addition, her conscious level improved rapidly, and she was extubated twenty-four hours following her cardiopulmonary arrest. This also suggests that an acute primary neurological pathology is unlikely since her symptoms were brief and transient. Moreover, a CT scan of her brain was reported as normal. Although the dose of quetiapine administered was small, we hypothesize that the patient's impaired hepatic function from ischaemic hepatitis, coupled with a reduced renal clearance due to ESRF, led to a transient rise in quetiapine levels which enhanced its effect, leading to respiratory depression and eventual cardiorespiratory arrest.

Dexmedetomidine may be a safer alternative than quetiapine for the treatment of ICU delirium. Table 1 illustrates that it has the best safety profile compared to commonly used drugs. Current recommendations also favour dexmedetomidine for the prevention of ICU delirium and for the treatment of refractory ICU delirium, including ICU patients who are not on mechanical ventilation $[3,8]$. Further studies are needed to determine its suitability as first line therapy for ICU delirium.

\section{CONCLUSION}

Small doses of quetiapine may cause profound Type 2 respiratory failure and cardiopulmonary arrest, especially in elderly, non-intubated patients with renal and hepatic impairment. Caution is needed when prescribing quetiapine for ICU delirium in such patients.

\section{CONFLICT OF INTEREST}

None to declare.

\section{DEFERENCES}

1. Wan RY, Kasliwalz M, McKenzie CA, Barrettz NA. Quetiapine in refractory hyperactive and mixed intensive care delirium: a case series. Crit Care. 2011;15(3):R159.

2. Kasliwal MR, McKenzie C, Barrett NA. Quetiapine in prolonged ICU delirium [abstract 497]. Crit Care. 2010;14(Suppl 1):P497.

3. Hayhurst CJ, Pandharipande PP, Hughes CG. Intensive care unit delirium: a review of diagnosis, prevention and treatment. Anesthesiology. 2016;25(6):1229-41.

4. Devlin JW, Roberts RJ, Fong JJ, et al. Efficacy and safety of quetiapine in critically ill patients with delirium: a prospective, multicentre, randomised, double-blind, placebo-controlled pilot study. Crit Care Med. 2010;38:419-27.

5. Michaud CJ, Bullard HM, Harris SA, Thomas WL. Impact of quetiapine treatment on duration of hypoactive delirium in critically ill adults: a retrospective analysis. Pharmacotherapy. 2015;35(8):731-9.

6. Freudenmann RW, Süssmuth SD, Wolf RC, Stiller P, SchönfeldtLecuona C. Respiratory dysfunction in sleep apnea associated with quetiapine. Pharmacopsychiatry. 2008;41(3):119-21.

7. Jabeen S, Pollo SI, Gerber DR. Acute respiratory failure with a single dose of quetiapine fumarate. Ann Pharmacother. 2006;40:559-62.

8. Cavallazzi R, Saad M and Marik PE. Delirium in the ICU: an overview. Ann of Intensive Care. 2012;2(1):49.

9. Lexi-drugs online [database on the Internet]. Hudson $(\mathrm{OH})$ : Lexicomp Inc.; 2019. Available from: http://online.lexi.com. Accessed July 19, 2019.

10. DeVane CL, Nemeroff CB. Clinical pharmacokinetics of quetiapine: an atypical antipsychotic. Clin Pharmacokinet. 2001;40(7):509-22.

11. Medication guide for Seroquel. U.S Food and Drug Administration. https://www.accessdata.fda.gov/drugsatfda_ docs/label/2020/020639s069lbl.pdf\#page=49. Updated 2019. Accessed May 13, 2020.

12. Ibrahim K, McCarthy CP, McCarthy KJ, et al. Delirium in the cardiac intensive care unit. J Am Heart Assoc. 2018;7(4):e008568. Published Feb 2018. Accessed May 1, 2020.

13. Czekalla J, Beasley CM Jr, Dellva MA, Berg PH, Grundy S. Analysis of the QTC interval during olanzapine treatment of patients with schizophrenia and related psychosis. J Clin Psychiatry. 2001;62(3):191-8.

14. Seafim RB, Bozza FA, Soares M, et al. Pharmacologic prevention and treatment of delirium in intensive care patients: a systematic review. J Crit Care. 2015;30(4):799-807. 
258 - The Journal of Critical Care Medicine 2020;6(4)

15. Balit CR, Isbister GK, Hackett LP, Whyte IM. Quetiapine poisoning: a case series. Ann Emerg Med. 2003;42(6):751-8.

16. Wang $M$, Tsai $C$, Lin CW, Yeh C, Wang Y, Lin H. Association
Available online at: www.jccm.ro

between antipsychotic agents and risk of acute respiratory failure in patients with chronic obstructive pulmonary disease. JAMA Psychiatry. 2017;74(3):252-260. 